\title{
Enhancing Writing Vocabulary Using Mentimeter
}

\author{
Pei Miin Wong* and Melor Md. Yunus \\ Universiti Kebangsaan Malaysia \\ Selangor, Malaysia
}

\begin{abstract}
This paper aimed to examine the effectiveness of using Mentimeter, which is an online virtual platform to enhance the writing vocabulary among pupils. By using Mentimeter, they can access the platform to collaborate with their peers and teacher regardless of the time frame, geographical and self-confident factors. This collaborative discussion platform would expand pupils' word bank and understanding about the writing task; thus helping them in accomplishing their writing tasks. An action research based on Kemmis and McTaggart model was carried out with 40 pupils with a marginal passing rate by using pre and post-test, questionnaire and unstructured interviews. The findings showed a significant difference between the results of pre and post-test and positive feedbacks from the pupils. In conclusion, Mentimeter is an effective tool to enhance pupils' writing vocabulary. The results of this study may be beneficial to educators in employing Mentimeter in teaching of writing vocabulary. However, this paper is only focused on the effectiveness of using Mentimeter to increase the vocabulary of pupils in writing within the targeted group thus further study is needed to ascertain the efficacy of using Mentimeter and to generalise the findings to a larger population.
\end{abstract}

Keywords: Mentimeter; vocabulary; writing; cooperative learning

\section{Introduction}

21st Century Learning is widely spread among education throughout the globe to ensure the learning of pupils is relevant to the globalisation of education. Proficiency needed in the 21st century differs from the previous centuries due to the emergence of the revolution of information and communication technologies (ICT) (James \& Ron, 2010) and the skills to learn and practice in daily life are changing rapidly, including the need to master learning and innovation skills, digital literacy and career and life skills (Bernie \& Charles, 2009). In other words, pupils nowadays are anticipated to be able to initiate their learning, collaborate with others while working, solve problems either critically or creatively, and

* Corresponding author: Pei Miin Wong, Email: dorricewong@gmail.com 
acquire different knowledge and information through a variety of media or ICT. To furnish the pupils with the 21st-century skills, they should be taught using the 21st-century teaching approach (Pamela et al., 2016) and ICT can be utilised as a learning tool in education (Yunus et al., 2013). According to Simin et al. (2016), "Due to ICT's importance in society as well as in the future of education, identifying the possible challenges to integrating these technologies in schools would be an important step in improving the quality of teaching and learning." It is undeniable that ICT plays an important role in the current trend of education as Dawes (2001) stated that current technologies can provide opportunities for adequate communication between teachers and pupils, thus the education seems to be able to revamp.

Clearly, the Malaysian government emphasise the innovation in ICT to improve teaching and learning processes as what mentioned in the Malaysian Education Blueprint 2013-2025. Thus, the education industry has been expected to prepare teachers, pupils as well as other people in this society to be competent in technologies, make use of it, and to contribute toward the attainment of the national goal, which is to transform Malaysia into a developed and worldknown country (Garba et al., 2015). The government therefore has implemented new policies with huge funds allocation to provide the infrastructure and facilities needed for ICT integration in the education industry (Ong \& Ruthven, 2009). For instance, Frog Virtual Learning Environment (VLE) was introduced in Malaysia public schools since 2012 as an extension from 1Bestari.net (MoE, 2016), the previous fundamental ICT in almost all schools in Malaysia. Frog VLE is a media-rich platform comprising various interactive activities and contents for teachers to share their teaching ideas in a trustworthy environment (Hew \& Syed Abdul Kadir, 2016). It was aiming to create a 21st-century learning environment (Kim et al., 2012) in Malaysian schools and to improve the teaching and learning process.

With the sufficient technologies provided in schools, it is hoped that teaching and learning of all subjects, including the learning of English as a second language (ESL) could be conducted in a way which fulfils the requirements of 21st-century learning. According to Cheok and Wong (2016), ICT enhances teaching and learning with pupils having the authority to access to more content that is more engaging and interactive and they will be responsible on their learning at their own pace. Educators, on the other hand, will have access to local and foreign resources to improve their teaching and learning. The assorted range of technologies available for use in language teaching and learning has promoted its functionality in language practice (Yunus, 2018) and it is relevant to the needs of improving the learning ESL, including the writing (Yunus, 2007).

However, the Malaysian Ministry of Education reported that VLE usage by teachers, students and parents was exceedingly low, that was between 0.01percent and 4.69percent in 2014 (MoE, 2014). The low participation of the above-mentioned parties were indeed reviewed in the statistic tabulated (Frog Asia, 2016), showing the usage of Frog VLE between 12-18 October 2015 by students, teachers and parents in Kuala Lumpur: 
Table 1: Usage of Frog VLE (12-18 October 2015) within primary and secondary schools in Kuala Lumpur (Frog Asia, 2016)

\begin{tabular}{|c|c|c|c|}
\hline Participants & Total number of. & Total logged in of. & Percentage \\
\hline Schools & 300 & 271 & $90 \%$ \\
\hline Teachers & 17955 & 4161 & $23 \%$ \\
\hline Students & 227652 & 13939 & $6 \%$ \\
\hline
\end{tabular}

Table 1 showed the usage of Frog VLE within schools in Kuala Lumpur. The result was indeed disappointing as Kuala Lumpur is the capital of Malaysia and is equipped with the best infrastructures, internet services and education resources. Despite internet and Frog VLE are provided to 90percent of the schools in the country, the usage of Frog VLE was at a very minimal rate where only 23percent of teachers and 6percent of pupils who logged in the VLE. It is undeniable that some of the participants might have just logged into their account, without really using it as many teachers commented that they were facing time constraint and it was rather troublesome to use Frog VLE as they were burdened with their heavy workload and unstable internet connections in schools (Norazilawati et al., 2013; Kaur \& Hussien, 2014).

Besides, the contract of the Malaysian Education Ministry with the network provider of Frog VLE, which is YTL Communications Sdn Bhd (YTLC) ended on 30th June 2019. According to "Ministry: We didn't terminate YTLC contract" (2019), the Education Ministry secretary-general Datuk Dr Mohd Gazali Abas mentioned that the ministry had paid YTLC around RM3.8billion for 1Bestari.net but the improvement of it was scarcely seen. The ministry as well needed to respond to schools', teachers' and parents' comments that 1BestariNet and Frog VLE were rather problematic. Therefore, the functionality and effectiveness of Frog VLE in the teaching and learning of ESL is certainly questionable and there is a need to look for an alternative to address the existing problem.

Moreover, the education system in Malaysia is still exam-oriented although the government is trying to improve the system by amending the syllabus, teaching methods, assessment means and variety ICT based teaching management system. Pupils who go for public schooling are required to receive six years of primary education and sit for the Malaysian Primary School Achievement Test (UPSR) by the end of their primary education. For English, pupils would have to sit for two papers: the comprehension paper and the written paper. Pupils are expected to acquire the language after six years of ESL learning. Surprisingly, "New UPSR Format Sees Big Drop in Straight A Scorers" (2016) reported 12\% of the candidates failed the comprehension paper while more than $23 \%$ of them failed to achieve the minimal passing grade for their English written paper in the 2016 UPSR and it showed slight improvement in the following years. Pupils could not answer the papers due to reasons. 


\subsection{Research Gap}

Due to that, the researcher had researched the inability of Year 4 pupils (aged 10) in writing because they are incapable in constructing correct sentences and due to the wide transition gap between the Year 3 (aged 9) and the Year 4 exam formats. Later, the researcher discovered that the Year 5 pupil (aged 11) in her school are as well unable to comprehend questions and to express their ideas accurately due to the lack of vocabulary; resulting them unable to complete the writing task and showing least interest in writing activities. It is similar to Rifaat (2019) who mentioned that "The lack of vocabulary, worry about having mistaken, have no idea to start writing, or have no good strategy to write are the common problems faced by the students when they are asked to write the paragraph." Meanwhile, it is also coherent to Ariyanti and Fitriana (2017) who supported that implementation of vocabulary is one of the difficulties faced by pupils in writing.

\subsection{Research Purpose}

To elucidate this problem, the researcher employed 'Mentimeter', a free webbased platform, to help pupils to increase their writing vocabulary. Barker and Gossman (2013) proved that virtual learning environment is capable of bringing a positive impact on pupils' learning. It increases their motivation to learn and promotes communication and cooperative learning. Thus, this study aimed to explore to what extent does 'Mentimeter' help in increasing pupils' writing vocabulary?

\section{Literature Review}

\subsection{Importance of VLE}

Virtual learning environment (VLE) has gradually gained its place within the education sector as the variety of tools and their functionality in supporting pupils, teachers and schools (Alves et al., 2016). It serves as a great learning tool and offers many features including communication facilities, document submissions, Information sharing, linking external sources; and embedding content in different forms (BBC Active, 2010). Bouhnik and Marcus (2006) have listed four advantages of e-learning, including the freedom to decide when each online lesson will be learnt, lack of dependence on the time constraints of the lecturer, freedom to express thoughts and ask questions without limitations and the accessibility to the course's online materials at students' selection. Zaki and Yunus (2015) also agreed that it is possible to integrate it into writing lessons so pupils could acquire knowledge in different ways and learn how to perform better in their writing task.

Eom (2012) conducted a study on the successfulness of the e-learning system based on the multi-dimensional research model developed by Wang, Wang and Shee (2007). In the study, 674 undergraduates participated in the survey. The data analysis showed that self-efficacy and satisfaction of the users are influenced by system and information quality. Besides, Eom (2012) also argued that expository power in understanding learners' satisfaction and effectiveness of the system in the e-learning context is restricted despite of its extensive success in other contexts. 
Thus, it is important to have VLE introduced in schools to promote an interactive learning system that has no limitations and boundaries. Pupils acan learn without any barrier and in a more flexible way. Therefore, pupils can reach out to the latest learning materials and gaining extra knowledge other than the textbooks. Likewise, low achievers are encouraged to learn at their own pace through the VLE platform as they are given chances to get back to the previous materials to have a better understanding. Alternatively, high performers are allowed to carry on with the following subject areas and certainly they are motivated to strive for a more desirable outcome in learning. Barker and Gossman (2013) also proved that virtual learning environment is capable of bringing a positive impact on pupils' learning by increasing their motivation to learn and promoting communication and collaborative learning.

On contrarily, there are also hiccups in using VLE. Leonardo (2017) mentioned that the capacity of laboratories, sufficient supply of computers and stability of internet connection remained the major challenges in implementing VLE. Chetwynd (2017) also argued that developing a VLE could be time-consuming as teachers were required to prepare and upload materials on the platform whilst some of them might be little or no experience in using websites in their practice. They also need to deliver the content beforehand so the learners could be on the right path of using the VLE within the given framework or task content. Besides, some of the learners might take VLE as a 'dumping ground' which they post and upload a variety of materials and information without proper organisation; and finally lead to frustration in using the sites. However, if the above-mentioned shortcomings are solved, the implementation of VLE would be beneficial to the learners (Leonardo, 2017).

\subsection{Mentimeter}

Mentimeter is an online, audience response system, which encourages interactive learning to take place (John, 2018). It becomes a popular tool among educators since 2014 (Mayhew, 2019) as it is a very convenient tool for both teachers and pupils, free and does not require further downloads nor installation (Jurgen, 2018; Puspa \& Imamyartha, 2019); thus reducing a lot of hassle during its usage. To use Mentimeter, pupils could enter a unique six-digit code to access to specific pages assigned by their teachers and start sending responses. The only criterion to use Mentimeter is that one must have access to the internet. In other words, Mentimeter can be used by pupils during the class as long as they are provided with internet and can engage pupils in real-time (Emma, 2018) and instant feedbacks, ideas and outcomes of discussions could be collected. The use of such electronic system or tool simultaneously encourages greater engagement and a higher participation rate and offers in-class anonymity which traditional discussions do not (Heaslip et al., 2014); and is useful in actively engaging students (Morrison, 2015).

Mentimeter promotes collaborative learning as it allows pupils to share their thoughts (Quang, 2018) as they post their ideas on the same page (Lina \& Annika, 2015). Also, pupils who lack of ideas or who have lower proficiency could refer to their peers' feedback, and try to express their thoughts; thus 
reducing negative participation in the class. It also "supports quality learning through encouraging interaction and discussion from even the most introverted students" (Crump \& Sparks, 2018).

Furthermore, researches showed that pupils expressed favouritism towards Mentimeter and recommended it be used by others as it provides variety for questions, layouts and most importantly, it does not preclude routine questions and answers of the pupils (Davina \& Kelly, 2017). According to Chris and Keele (2016), "Mentimeter offers highly-customisable activities which can facilitate an instant analysis of responses, provide downloadable data sets and create an interactive teaching and learning experience for groups of varying sizes." Therefore, it is indeed a suitable tool to use in education, especially in the learning of English (Puspa \& Imamyartha, 2019).

\subsection{Writing Vocabulary}

Vocabulary is one of the important language elements that one must acquire in mastering a language (Bambang \& Utami, 2008). Vocabulary is defined as all the words in a particular language (Wehmeier et al., 2005). The language learners need to learn vocabulary because "the building blocks of language learning and communication are not grammar, function, notions, or some other unit of planning and teaching but lexis, that is, word and word combinations" (Richards \& Rodgers, 2001).

In language learning, writing is one of the components which strongly related to vocabulary learning as studies shown that there is a significant relationship between vocabulary knowledge and academic performance (Ruth, 2016). "Written language is far more complex than spoken language in terms of organisation, vocabulary, and sentence structure," (Cudd \& Roberts, 1993). Olinghouse \& Leaird (2009) also defined that vocabulary in writing symbolises the maturity and authenticity of written work produced by ESL learners. According to Alfaki (2015), people can share their ideas, feelings, persuading and convincing others through their writing; and some people may write for personal enjoyment. Sufficient vocabulary is the key factor to produce meaningful and comprehensible written work. If the vocabulary acquired by the learners is insufficient, the written production would not be perceived (Maskor \& Baharudin, 2016). Research has shown that lack of vocabulary contributes to writing difficulty for ESL learners (Santos, 1988).

However, many pupils are unable to perform in their writing task due to limited exposure to the language and for their lack of vocabulary and language skills (Daud et al., 2005; Linse, 2005; Nguyen \& Dong, 2015); and "Knowing a word's definition is not all that can be learned about a word" (Marco, 2018). To produce a piece of good writing, it is necessary to enrich the vocabulary of the pupils (Cindy et al., 2018) by providing a certain level of understanding. Pupils as well, are concerned over the teachers' feedback on their writing and their word choice (Karakoc \& Kose, 2017). According to Bakhsh (2016), teaching vocabulary through interesting means is important to ESL learners because they sustain enjoyment and interest in learning and use the vocabulary learned more creatively. Thus, the use of Mentimeter in teaching vocabulary is considered as an interesting way for learners to engage in the learning activities. 


\subsection{Cooperative Learning}

Learning is an on-going process involving interaction between educators and learners; learners and learners; and learners and the learning resources in a learning environment. In other words, both learners and educators need to cooperate to ensure learning takes place. Cooperative learning is an educational approach which aims to organize classroom activities into academic and social learning experiences. Li and Lam (2013) defined cooperative learning as "A student-centred, instructor-facilitated instructional strategy in which a small group of students is responsible for its own learning and the learning of all group members." According to Slavin (1995), "In cooperative learning methods, student work together in four-member teams to master material initially presented by the teacher." Anita Lie (2000) also mentions that cooperative learning takes place when a group of four to six people work together towards the goals that have been determined. It can be argued that cooperative learning can arouse pupils' interest and enthusiasm in learning; thus optimum results could be achieved.

Isjoni (2010) has identified six benefits of cooperative learning for pupils in English. For instance, positive interdependence or the reciprocal relationship that is based on a common interest or feelings among the group members, the recognition of individual differences in responses while face to face interaction or discussing takes place, pupils are involved in planning and classroom management including what to study and when to study, relax and fun classroom atmosphere, the establishment of a warm and friendly relationship between pupils and teachers and opportunities to express one's idea. It is undeniable that some of the pupils are introvert and reluctant to participate in the traditional classroom discussions. Thus, a virtual discussion might help them to build a reciprocal relationship with their peers.

\subsection{Conceptual Framework}

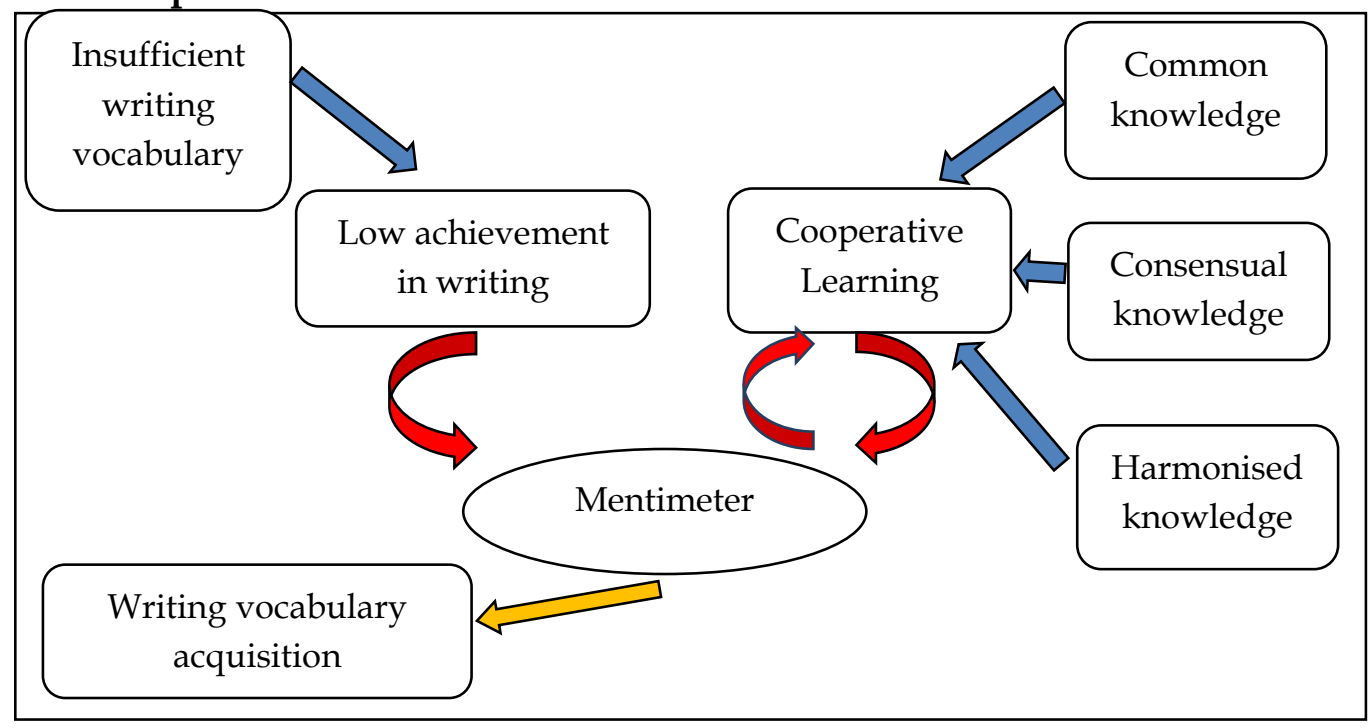

Figure 1: Conceptual framework of the study 
The framework of the study is as shown in the Figure 1. It is divided into three main parts, which are the reasons for the implementation of Mentimeter, the underpinning theory and the outcomes of using Mentimeter. From the observations made by the researchers, pupils have shown dissatisfactory achievement in their UPSR written paper due to several factors, including the factors being explored in this study, which is the insufficient writing vocabulary among pupils. The second part concentrates on the cooperative learning among pupils. Mentimeter is a tool which promotes cooperative learning. The pupils with common knowledge, or the vocabulary they know in this study, contributed and cooperated with their peers and produced the harmonised knowledge at the end of the implementation of Mentimeter, which is the vocabulary they can use in respective writing tasks. Next, the benefits of using Mentimeter are being discussed in this study. The investigated aspects including the acquisition of writing vocabulary by using Mentimeter in teaching and learning of writing vocabulary are discussed in this study.

\section{Material and Method}

To study the effectiveness of Mentimeter in enhancing writing vocabulary among year 5 pupils, the researcher employed action research in a primary school in Seri Kembangan, Selangor. When referring to Roscoe (1975), the appropriate sample size for a study ranged from 30 to 500 and the use of sample size about 10per cent is recommended. The population consists of 342 pupils. Thus, purposive sampling was adopted by the researchers where 40 pupils (11.7per cent) from a class were chosen as the samples in this study. They are placed in the class at the beginning of the year because of their average achievement in all the co-subjects being taught in school including English. Hence, the study concentrated on the results of Mentimeter in enhancing their writing vocabulary.

Next, data was collected through both quantitative and qualitative method. Firstly, pre and post-test had been administered before and after the implementation of Mentimeter to evaluate the ability of pupils to use appropriate and effective vocabulary in writing. The same material and test questions were used for both pre-test and post-test. The test was designed in a way that pupils were required to write a descriptive essay based on a series of 3 pictures given. 5 words are given in each picture to aid the pupils in their writing. The work was read as a whole and marked by the teacher in school following a scheme similar to the UPSR marking scheme, with 80-100 marks for pieces with sophisticated sentences, well-planned ideas and effective use of vocabulary; 60-79 marks for pieces with well-planned ideas, minimal errors in the sentences, correct use of vocabulary; 40-59 marks for pieces with ideas which are generally well-planned, some errors in the sentences and correct use on some vocabulary; 20-39 marks for pieces with attempts to sequence ideas logically, multiple errors in the sentences and attempts to use vocabulary in very limited range; and 1-19 marks for pieces with chunking of ideas and very limited use of vocabulary. The means of the tests were compared. Inferential data analysis had also been carried out to identify the significant difference between the results. 
Then, the researchers surveyed the use of Mentimeter to investigate the effectiveness of Mentimeter in enhancing their writing vocabulary. The researchers adopted the investigator-administered questionnaire where the questionnaires were filled up in the presence of the researcher to assist the pupils when there is a need. Besides, the pupils answered the questionnaires in a classroom with separated sittings, thus no discussion was made among them during the process of answering the questionnaire. Furthermore, pupils are required to answer the questionnaire on their own pace, thus reducing anxiety caused by a limited period. The questionnaire consist of 2 sections: 3 questions about the demographic profiles of the pupils and 10 questions about the research question. All the questions in the questionnaire are closed-ended questions with a four-point Likert scales: strongly disagree (S.D), disagree (D), agree (A) and strongly agree (S.A). The choice for neutral was omitted from the scales as Asians tend to choose the midpoint on the scales (Lee et al., 2002). The data obtained from the questionnaire was analysed, tabulated and discussed in the following section to obtain the average responses of the pupils towards the effectiveness of Mentimeter in enhancing their writing vocabulary.

As for qualitative data, an unstructured interview was conducted with 5 of the pupils who participated in the study. The interviews were conducted after the completion of questionnaires to identify if the use of Mentimeter can solve the problems faced by the pupils. The pupils who participated in the interviews were interviewed by the researcher individually in the classroom as mentioned above. The feedback from the pupils were recorded, transcribed and further elaborated to support the findings of the study.

\section{Results and Discussion}

This study aimed to find out the effectiveness of Mentimeter in enhancing pupils' writing vocabulary. The results derived from the pre and post-test are presented in Figure 2.

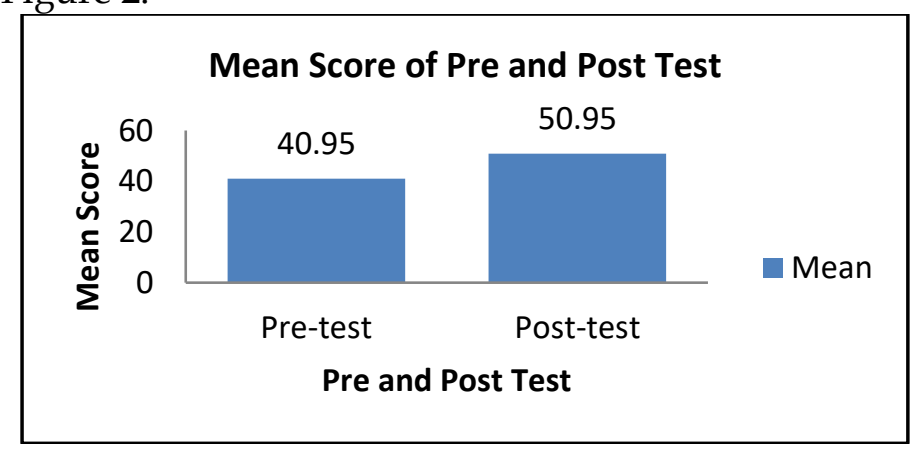

Figure 2: Comparison of mean between pre-test and post-test

For pre-test, pupils obtained total marks of 1638 with a mean score of 40.95 . For post-test, pupils obtained 2038 marks with a mean score of 50.95. The rise of 10 mean score indicates the pupils had completed their writing task and performed better in their post-test. 
Table 2: Test of normality

\begin{tabular}{|c|c|c|c|}
\hline \multirow{2}{*}{ Test } & \multicolumn{3}{|c|}{ Shapiro-Wilk } \\
\cline { 2 - 4 } & Statistic & $\mathbf{d f}$ & Sig. \\
\hline Pretest & .971 & 40 & .382 \\
\hline Posttest & .967 & 40 & .287 \\
\hline
\end{tabular}

According to Riffenburgh (2012), normality of a distribution could be tested by using the Shapiro-Wilk test when the sample size, $n<50$. Since there were only 40 samples in this study, Shapiro-Wilk test had been conducted and the data collected are normal with sig. $=0.382$ for pre-test and sig. $=0.287$ for post-test, $p>0.05$; therefore parametric test was used in this study.

Table 3: Paired sample T-test

\begin{tabular}{|c|c|c|c|c|c|c|}
\hline \multicolumn{7}{|c|}{ Paired Differences } \\
\hline & Mean & Std. Deviation & Std. Error Mean & $\mathbf{t}$ & $\mathbf{d f}$ & $\begin{array}{c}\text { Sig. (2- } \\
\text { tailed) }\end{array}$ \\
\hline $\begin{array}{l}\text { Pretest- } \\
\text { Posttest }\end{array}$ & -9.500 & 4.194 & .663 & -14.326 & 39 & .000 \\
\hline
\end{tabular}

Later, paired two-sample t-test has also been done to compare the difference between means for pre-test and post-test. According to Kitchin and Tate (2013), $p<0.05$ would indicate a significant result and often termed 'highly significant'. The study has shown a significant difference between means for pre-test and post-test with $\mathrm{t}(39)=-14.326, \mathrm{p}<0.05$.

The pre-post test results indicated the use of Mentimeter can help pupils to achieve better learning outcomes, which is the ability to complete their writing task. From what the researcher had observed, the post-test done by the pupils reflected better use of vocabulary in constructing correct sentences and presenting ideas. The use of Mentimeter is showing significant results towards pupils' writing vocabulary. However, it is not to forget that the same material and test questions were used for both pre-test and post-test. The post-test was carried out a month later than the pre-test. Although the pupils were not informed that the questions would be the same, they did know that there would be another test after the use of Mentimeter, as mentioned by one of the pupils, "My teacher already told us that there will be another test, a similar one, after we finished the program." It is undeniable some of the pupils might have revised on what they had done in the pre-test and had prepared themselves for the posttest; which their actual ability to use the vocabulary in their writing is not tested. According to one of the pupils,

"We already know that there will be another test. So, I did some revision at home. I remembered the words we learned in class and found something similar in my books. I'm quite lucky that I read the essay before, thus I can write better in the second test." 
Thus, the effectiveness of Mentimeter is investigated through the following questionnaire.

Table 4: Effectiveness of Mentimeter in improving writing vocabulary

\begin{tabular}{|c|c|c|c|c|c|c|}
\hline No. & Item & S.D & $\mathbf{D}$ & $\mathbf{A}$ & S.A & Mean \\
\hline 1. & $\begin{array}{l}\text { Mentimeter helps in improving my } \\
\text { writing vocabulary. }\end{array}$ & 2 & 4 & 20 & 14 & 3.15 \\
\hline 2. & $\begin{array}{l}\text { I posted the vocabulary that I know on } \\
\text { Mentimeter. }\end{array}$ & 0 & 8 & 21 & 11 & 3.08 \\
\hline 3. & $\begin{array}{l}\text { I learn vocabulary posted by my friends } \\
\text { on Mentimeter. }\end{array}$ & 3 & 6 & 12 & 19 & 3.68 \\
\hline 4. & $\begin{array}{l}\text { I understand more vocabulary given in } \\
\text { my writing task. }\end{array}$ & 2 & 12 & 18 & 8 & 2.80 \\
\hline 5. & I can use more vocabulary in my writing. & 0 & 4 & 23 & 13 & 3.23 \\
\hline 6. & I am more confident in my writing. & 2 & 2 & 22 & 14 & 3.20 \\
\hline 7. & I think Mentimeter is useful. & 0 & 2 & 21 & 17 & 3.38 \\
\hline 8. & I think Mentimeter is not useful at all. & 29 & 11 & 0 & 0 & 1.28 \\
\hline 9. & I will continue to use Mentimeter. & 2 & 2 & 23 & 13 & 3.18 \\
\hline 10. & $\begin{array}{l}\text { I will introduce Mentimeter to my } \\
\text { friends. }\end{array}$ & 0 & 3 & 24 & 13 & 3.25 \\
\hline
\end{tabular}

Based on the results derived from the questionnaire, pupils reflected that they collaboratively learned vocabulary by using Mentimeter (mean=3.68) and acknowledged Mentimeter as a useful tool in learning vocabulary (mean=3.38). A pupil stated that:

"Sometimes I really can't think of the right vocabulary to use on the theme given by my teacher. But, when I look at the answers posted by my friends, I got some ideas and they help me in getting more words for my writing."

Another pupil also mentioned that, "My English is not good. My friends' answers helped me a lot." Mentimeter allows pupils to brainstorm ideas and indirectly, they can learn from one another. Generally, the feedbacks of the pupils are coherent to Quang (2018) who concluded Mentimeter as a collaborative learning tool as it promotes idea sharing among the users. However, there was one pupil who responded differently, "Although this app is not bad, I think some of my friends copied my answer and I'm not happy with that." Besides, pupils also complied that Mentimeter had provided them with more writing vocabulary (mean=3.23), thus making them to be more confident in completing their writing task (mean=3.20). 
"I think I've learned a lot of vocabulary by using Mentimeter," commented by one of the pupils. The other pupil also responded that:

"Last time I don't know what the right words to use in my writing are. My teacher always put a lot of wavy lines in my exercise, saying that I'm using the wrong vocabulary. Mentimeter helps me to learn a lot of new vocabulary needed for my writing."

Based on the statement above, the pupil thought that Mentimeter has provided them with the necessary vocabulary in producing better writing. She added that, "I feel really upset when I see a lot of wavy lines in my essay. But now, I feel better as I've some improvements. I think I can do better next time." Also, most of the pupils $($ mean=3.18) agreed that they would continue to use Mentimeter in their future writing task and recommend the tool to their friends (mean=3.25). "I enjoy using Mentimeter. I think it is very good as it helps me a lot in getting the right words for my writing. I wish I can still use it after this, and maybe with my friends" responded by one of the pupils. Another pupil also stated that:

"I don't want to stop using it. It gives me a lot of ideas on vocabulary that I can use in my essay. Furthermore, it is fun to learn this way, where my friends and I can learn from one another. It is interesting to see different answers popping out on the Mentimeter."

It is in conjunction with Atay and Ozbulgan (2007) who stated online vocabulary teaching can provide individualised language learning experience and raise the awareness of language learning strategies which learners can utilise it in their studies after leaving the language classroom.

\section{Conclusion}

Based on the results and data gathered from the 40 pupils who participated in this study, it is clearly shown that the use of Mentimeter has significant results towards pupils' writing vocabulary and leading them to outperform in their writing task. The findings imply that pupils agreed Mentimeter is an effective tool which enables them to enhance their writing vocabulary and provide them with a collaborative learning environment. They were comfortable to learn from their peers and indirectly increase their confidence in completing their writing task. Thus, it is hoped that educators should be aware of the functionality and potential of Mentimeter, and integrate it in their teaching and learning process. However, this paper is only focused on the effectiveness of using Mentimeter to increase the vocabulary of pupils in writing within the targeted group thus further study is needed to ascertain the efficacy of using Mentimeter in teaching and learning of other language skills, such as grammar items, so the pupils would be beneficial from the studies and to generalise the findings to a larger population.

\section{Recommendations}

Based on the findings of this study, the researcher would like to suggest a few factors to be investigated in the future. First of all, Mentimeter is a real-time responses tool. In this study, the pupils used Mentimeter for the teaching and 
learning of writing vocabulary during school hours. It means pupils need to use it together, at one time, to achieve the optimum results. Therefore, pupils would not be able to learn through Mentimeter if less people are using it at the same time. There is a need to find out the effectiveness of Mentimeter in teaching and learning practices for classrooms with fewer pupils.

Besides, this study is conducted with 40 Year 5 pupils in Selangor, who were selected purposively based on their exam results. The effectiveness of Mentimeter in enhancing pupils' writing vocabulary might not be the same if it is conducted elsewhere with other pupils. Hence, further studies are needed to be done with a larger sample size so the results of the studies could be generalised to a larger population.

\section{Implications}

This study is beneficial for the pupils as they acquired more writing vocabulary. They can use the vocabulary more effectively in their writing. This will help them to produce better writing and achieve better grades when they sit for the written test. Next, Mentimeter serves a modern learning tool for the pupils. They no longer need to study everything using the traditional approaches. It makes their lesson fun and engages them in the teaching and learning activities. It also gives opportunities for pupils with higher proficiency to facilitate the weaker pupils by modelling their answers. Besides, this study has offered a new teaching tool to the teachers. Teachers could adapt Mentimeter in their classrooms, regardless of which subjects they are teaching, as it is coherent to the needs of $21^{\text {st }}$-century education. The teachers need to ensure that they are equipped with computer and internet literacy so they could implement it in their practice.

\section{References}

Alfaki, I. M. (2015). University students' English writing problems: Diagnosis and Remedy. International Journal of English Language Teaching, 3(3), 40-52.

Alves, P., Miranda, L., \& Morais, C. (2019). The Importance of Virtual Learning Environments in Higher Education. In I. Management Association (Ed.), Computer-Assisted Language Learning: Concepts, Methodologies, Tools, and Applications (pp. 109-131). Hershey, PA: IGI Global. doi:10.4018/978-1-5225-76631.ch005

Anita, L. (2000). Cooperatif Learning. Jakarta. Alfabeta : Grafindo.

Ariyanti, A., \& Fitriana, R. (2017). EFL students' difficulties and needs in essay writing. In the Proceedings of the International Conference on Teacher Training and Education 2017 (ICTTE 2017). ISSN: 2352-2398. doi:10.2991/ictte-17.2017.4

Atay, D., \& Ozbulgan, C. (2007). Memory strategy instruction, contextual learning and ESP vocabulary recall. English for Specific Purposes, 26(1), 39-51. doi:10.1016/j.esp.2006.01.002

Bakhsh, S. A. (2016). Using games as a tool in teaching vocabulary to young learners. English Language Teaching, 9(7), 120-128. doi: 10.5539/elt.v9n7p120

Bambang, Y. C., \& Utami, W. (2008). The teaching of EFL vocabulary in the Indonesian context: The state of the art. TEFLIN Journal, 19(1), 1-17. Retrieved from http://journal.teflin.org/index.php/journal/article/view/94 
Barker, J., \& Gossman, P. (2013). The learning impact of virtual learning environment: Students' view. Teacher Education Advancement Network Journal, 5(2), 19-38.

BBC Active. (2010). Why you should use a Virtual Learning Environment. [Online] Retrieved from

http://www.bbcactive.com/BBCActiveIdeasandResources/Whyyoushouldusea VirtualL earningEnvironment.aspx

Bernie, T., \& Charles, F. (2009). 21st Century Skills: Learning for Life in Our Times. San Francisco: Jossey-Bass.

Bouhnik, D., \& Marcus, T. (2006). Interaction in distance-learning courses. Journal of the American Society Information Science and Technology, 57(3), 299-305.

Cheok, M. L., \& Wong, S. L. (2016). Frog virtual learning environment for Malaysian schools: Exploring teachers' experience. Lecture Notes in Educational Technology, 201-209. doi:10.1007/978-981-10-0373-8_10

Chetwynd, A. (2017). VLE based analysis and design. The Plymouth Student Scientist, 10(1), 102-142.

Chris, L., \& Keele, U. (2016). Mentimeter smartphone student response system: A class above clickers. Journal of Learning and Teaching, 9(13). doi:10.21100/compass.v9i13.328

Cindy, F. V., Desiani, N. M., \& Winti, A. (2018). Developing students' critical writing skills of elementary school by using vocabulary chart. EduHumaniora: Jurnal Pendidikan Dasar, 10(2), 148-153. doi:10.17509/eh.v10i2.10870

Crump, V., \& Sparks, J. (2018). Game of phones: Integrating mobile technology into science and engineering classrooms. In the Proceedings of the 4th International Conference on Higher Education Advances (HEAd'18), 247-255. doi:10.4995/head18.2018.7971

Cudd, E. T., \& Roberts, L. L. (1993). A scaffolding technique to develop sentence sense and vocabulary. The Reading Teacher, 47(4), 346-349.

Daud, N. S. M., Daud, N. M., \& Kassim, N. L. A. (2005). Second language writing anxiety: Cause or effect? Malaysian Journal of ELT Research (MaJER), 1(1). Retrieved from http://www.melta.org.my/journals/index.php/majer/article/view/189/101

Davina, H., \& Kelly, F. (2017). Using Mentimeter to promote student engagement and inclusion. Pedagogy in Practice Seminar (18 th December 2017), UK: Fusehill Street, Carlisle. Retrieved from http://insight.cumbria.ac.uk/id/eprint/3473/

Dawes, L. (2001). What stops teachers using new technology? Teaching using ICT. London: Routledge.

Emma, M. (2018). No longer a silent partner: How Mentimeter can enhance teaching and learning within political science. Journal of Political Science Education, 15(4), 546551. doi:10.1080/15512169.2018.1538882

Eom, S. B. (2012). Effects of LMS, self-efficacy, and self-regulated learning on LMS effectiveness in business education. Journal of International Education in Business, 5(2), 129-144. doi:10.1108/18363261211281744

Frog Asia. (2016). Unit Pembestarian Sekolah [School Preservation Unit]. Retrieved from http://btpnkl.weebly.com/frogvle.html

Garba, S, Byabazaire, Y., \& Busthami, A. H. (2015). Toward the use of 21st century teaching-learning approaches: The trend of development in Malaysian schools within the context of Asia Pacific. International Journal of Engineering $\mathcal{E}$ Technology, 10(4), 72-79. doi:10.3991/ijet.v10i4.4717

Heaslip, G., Donovan, P., \& Cullen, J. G. (2014). Student response systems and learner engagement in large classes. Active Learning in Higher Education, 15(1), 11-24. doi:10.1177/1469787413514648 
Hew, T.-S., \& Syed Abdul Kadir, S. L. (2016). Behavioural intention in cloud-based VLE: An extension to Channel Expansion Theory. Computers in Human Behavior, 64, 920. doi:10.1016/j.chb.2016.05.075

Isjoni. (2010). Pembelajaran Kooperatif Meningkatkan Kecerdasan Komunikasi Antara Peserta Didik [Cooperative Learning Improves Communication Intelligence Between Students]. Yogyakarta: Pustaka Pelajar.

James, B., \& Ron, B. (2010). 21st Century Skills: Rethinking How Students Learn. Bloomington: Solution Tree Press.

John, I. (2018). Mentimeter. School Librarian, Autumn 2018: 153. Academic OneFile, $\begin{array}{llll}\text { Retrieved } & 17 & \text { June } & 2019\end{array}$ https://go.galegroup.com/ps/anonymous?id=GALE\%7CA555409973\&sid=goo gleScholar\&v $=2.1 \& i t=r \& l i n k a c c e s s=a b s \& i s s n=00366595 \& p=A O N E \& s w=w$

Jurgen, R. (2018). A brief review of Mentimeter - A student response system. Journal of Applied Learning \& Teaching, 1(1), 35-37. doi:10.37074/jalt.2018.1.1.5

Karakoc, D., \& Kose, G. D. (2017). The impact of vocabulary knowledge on reading, writing and proficiency scores of EFL learners. Journal of Language and Linguistic Studies, 13(1), 352-378.

Kaur, T., \& Hussien, N. (2014).Teachers' Readiness to Utilize Frog VLE: A Case Study of a Malaysian Secondary School. Journal of Education, Society \& Behavioral Science, 5(1), 20-29. doi:10.9734/bjesbs/2015/11965

Kim, H., Choi, H., Han, J., \& So, H. J. (2012). Enhancing teachers ICT capacity for the 21st century learning environment: Three cases of Teacher education in Korea. Australian Journal of Educational Technology, 6, 965-982. doi:10.14742/ajet.805

Kitchin, R., \& Tate, J. T. (2013). Conducting Research in Human Geography: Theory, Methodology and Practice. New York: Routledge Taylor and Francis Group. doi:10.4324/9781315841458

Lee, J. W., Jones, P. S., Mineyama, Y., \& Zhang, X. E. (2002). Cultural differences in responses to a Likert scale. Research in Nursing and Health, 25(4), 295-306. doi:10.1002/nur.10041

Leonardo, H. M. (2017). Impact of implementing a virtual learning environment (VLE) in the EFL classroom. Íkala, Revista de Lenguaje y Cultura, 22(3), 479-498. doi:10.17533/udea.ikala.v22n03a07

Li, M. P., \& Lam, B. H. (2013). Cooperative learning. The Hong Kong Institute of Education. Retrieved from https:// www.eduhk.hk/aclass/Theories/cooperativelearningcoursewriting_LB H\%2024June.pdf

Lina \& Annika. (2015). Active learning of information literacy with gamification and Mentimet. The Third European Conference on Information Literacy (ECIL), Tallinn, Estonia, 132.

Linse, T. C. (2005). Practical English Language Teaching: Young Learners. New York: McGraw Hill.

Malaysian Ministry of Education. 2014. Maklum balas ke atas Laporan Ketua Audit [Feedback on the Auditor General's Report]. Retrieved from https://www.audit.gov.my/index.php/ms/auditor/archives/federalarchives/534-laporan-ketua-audit-negara-persekutuan-2014-2

Marco, A. B. (2018). Open-ended vocabulary assessments. Wiley Online Library. doi:10.1002/9781118784235.eelt0836

Maskor, Z. M., \& Baharudin, H. (2016). Receptive Vocabulary knowledge or productive vocabulary knowledge in writing skill, which one important? International Journal of Academic Research in Business and Social Sciences, 6(11), 261-271. doi: 10.6007/ijarbss/v6-i11/2395 
Mayhew, E. (2019). No longer a silent partner: How Mentimeter can enhance teaching and learning within Political Science. Journal of Political Science Education, 15(4), 1-6. doi:10.1080/15512169.2018.1538882

Ministry of Education (MoE). (2016). 1BestariNet Kementerian Pendidikan Malaysia. Retrieved from http://1bestari.net.

Ministry: We didn't terminate YTLC contract (2019, Jul 06). The Star Newspaper. Retrieved from https://www.thestar.com.my/news/nation/2019/07/06/ministry-we-didntterminate-ytlc-contract

Morrison, J. (2015). The Effects of Electronic Response Systems on Student Learning. Western Michigan University. Master's Theses. 575. Retrieved from https://scholarworks.wmich.edu/masters_theses/575

New UPSR format sees big drop in straight A scorers (2016, November 18). The Star Newspaper. Retrieved from https://www.thestar.com.my/news/nation/2016/11/18/new-upsr-formatsees-big-drop-in-straight-a-scorers/

Nguyen, T. H., \& Dong, T. (2015). Problems affecting learning writing skill of grade 11 at Thong Linh high school. Asian Journal of Educational Research, 3(2), 53-69.

Norazilawati, A., Noraini, M. N., \& Nik, A. N. Y. (2013). Aplikasi persekitaran pengajaran maya (FROG VLE) dalam kalangan guru Sains [Application of virtual teaching environment (FROG VLE) among Science teachers]. Jurnal Pendidikan Sains \& Matematik Malaysia, 3(2), 63-75.

Olinghouse, N. G., \& Leaird, J. T. (2009). The relationship between measures of vocabulary and narrative writing quality in second- and fourth-grade students. Reading and Writing, 22(5), 545-565. doi:10.1007/s11145-008-9124-z

Ong, E., \& Ruthven, K. (2009). The effectiveness of Smart Schooling on student's attitudes toward science. Eurasia Journal of Mathematics, Science and Technology Education, 5, 35-45. doi:10.12973/ejmste/75255

Pamela, L. M. S., Yunus, M. M., \& Mohamad, M. (2016). The Malaysian education blueprint 2013 and its effects on English language teaching in Malaysia. Asian EFL Journal, 4, 58-171.

Puspa, A., \& Imamyartha, D. (2019). Experiences of social science students through online application of Mentimeter in English Milieu. IOP Conf. Series: Earth and Environmental Science, 243. In the Proceedings of the First International Conference on Environmental Geography and Geography Education (ICEGE) 17-18 November 2018, University of Jember, East Java, Indonesia. doi:10.1088/1755-1315/243/1/012063

Quang, P. (2018). Utilizing electronic devices in English-speaking Vietnamese university classrooms. In the Proceedings of the $5^{\text {th }}$ International Foreign Language Learning and Teaching Conference (FLLT 2018), 121-129.

Richards, J. C., \& Rodgers, T. S. (2001). Approaches and Methods in Language Teaching (2nd ed.). Cambridge: Cambridge University Press.

Rifaat, A. A. (2019). Story circle technique to help non-English major students in writing narrative text. Journal of Language Teaching and Learning, Linguistic and Literature, 7(1), 103-108. doi:10.24256/ideas.v7i1.726

Riffenburgh, R. H. (2012). Statistics in Medicine. California: Elsevier.

Roscoe, J. T. (1975). Fundamental Research Statistics for the Behavioral Sciences. (2nd Ed.). New York: Holt, Rinehart and Winston

Santos, T. (1988). Professors' reactions to the academic writing of non-native speaking students. TESOL Quarterly, 22, 69-88. doi: 10.2307/3587062 
Simin, G., Thanusha, K., Logeswary, R., \& Annreetha, A. (2016). Teaching and learning with ICT tools: Issues and challenges from teachers' perceptions. Journal of Educational Technology, 4(2), 38-57. Retrieved from https:// files.eric.ed.gov/fulltext/EJ1096028.pdf

Slavin, R. E. (1995). Research on Cooperative Learning and Achievement: What We Know, What We Need to Know. Johns Hopkins University. doi:10.1006/ceps.1996.0004

Wang, Y. S., Wang, H. Y., \& Shee, D. Y. (2007). Measuring e-learning systems success in an organizational context: Scale development and validation. Computers in Human Behavior, 23(4), 1792-1808. doi:10.1016/j.chb.2005.10.006

Wehmeier, S., McIntosh, C., Turnbull, J., \& Ashby, M. (2005). Oxford Advanced Learner s Dictionary of Current English. Oxford: Oxford University Press.

Yunus, M. M. (2018). Innovation in education and language learning in 21st century. Journal of Sustainable Development Education and Research, 2(1), 33-34. doi:10.17509/jsder.v2i1.12355

Yunus, M. M. (2007). Malaysian ESL teachers' use of ICT in their classrooms: expectations and realities. European Association for Computer Assisted Language Learning. ReCALL, 19(1), 79-95. doi:10.1017/s0958344007000614

Yunus, M. M., Nordin, N., Salehi, H., Embi, M. A., \& Salehi, Z. (2013). The use of information and communication technology (ICT) in teaching ESL writing skills. English Language Teaching, 6(7), 1-8. doi:10.5539/elt.v6n7p1

Zaki, A. A., \& Yunus, M. M. (2015). Potential of mobile learning in teaching of ESL academic writing. English Language Teaching, 8(6), 11-19. doi:10.5539/elt.v8n6p11 